\section{Australian Journal of \\ Crop Science}

\title{
Peruvian carrot (Arracacia xanthorrhiza Bancroft) as raw material for producing special native starches
}

\author{
Magali Leonel $^{1 *}$, Ezequiel Lopes do Carmo ${ }^{1}$, Célia Maria Landi Franco ${ }^{2}$, Adalton Mazetti Fernandes ${ }^{1}$, \\ Emerson Loli Garcia ${ }^{1}$, Thaís Paes Rodrigues dos Santos ${ }^{1}$
}

\author{
${ }^{1}$ Center for Tropical Roots and Starches (CERAT), São Paulo State University (UNESP), Botucatu, São Paulo, \\ Brazil \\ ${ }^{2}$ Department of Food Engineering and Technology, Institute of Biosciences, Language, and Physical Sciences, \\ São Paulo State University (UNESP), São José do Rio Preto, São Paulo, Brazil
}

\section{*Corresponding author: mleonel@ cerat.unesp.br}

\begin{abstract}
The use of natural starches in food or non-food industries is difficult, as there are no starches with essential properties for a particular application. Thus, it is important to identify different alternative starch sources with wide variability in starch properties. The aim of this study was to evaluate roots production and starch properties of Peruvian carrot genotypes [BGH clones (4560, 5741, 5744, 5746, 5747, 6414, 6513, 6525, 7609) and "Amarela de Senador Amaral" cultivar] growing in Brazil. The experimental design was randomized complete block design with four replications. After eight-month growing of Peruvian carrot plants, roots were collected and the total production of roots, and their dry matter and starches contents were analyzed. The roots were processed for starch extraction. Starches were evaluated for phosphorus and amylose contents as well as for thermal and pasting properties. Results showed differences for all parameters analyzed for roots and starches between materials. Peruvian carrot starches presented varied chemical, thermal and pasting properties which can be exploited by food industry as native starches.
\end{abstract}

Keywords: Amylose; Arracacia xanthorrhiza; crop production; phosphorus; viscosity.

Abbreviations: $\mathrm{P}_{-}$phosphorus, $\mathrm{T}_{0 \_}$initial temperature; $\mathrm{T}_{\mathrm{p} \_}$peak temperature; $\mathrm{T}_{\mathrm{f}-}$ final temperature; $\Delta \mathrm{T}_{-}$range of temperature; $\Delta \mathrm{H} \_$enthalpy change; $T P \_$pasting temperature; PV_peak viscosity; BK_breakdown; FV_final viscosity; SB_setback.

\section{Introduction}

The Peruvian carrot is an important starchy crop due to culinary, medicinal and nutritional attributes from its roots, which has allowed great applicability in processed food formulations (Heredia Zárate et al., 2008; Heredia Zárate et al., 2010; Pedreschi et al., 2011). Other aspects such as the characteristics of its starch and use of hand labor during cultivation are also highlighted as important aspects to the growing importance of this tuberous as industrial raw material (Vietmeyer, 1986; Graciano et al., 2007; Takeiti et al., 2007).

Brazil is the world's largest producer of Peruvian carrot with average production of 250 thousand tons per year, with about $95 \%$ of this volume has been intended for trade roots in nature and a small portion used by the food industry, where it is applied in the formulation of baby food, soups and purees (Pires and Finardi-Filho, 2005).However, with the change in eating habits of the world population leading to growth in the consumption of processed or semi-finished products, the percentage of sales of fresh roots has declined considerably in large urban centers, which is why there is great demand for studies in the processing of Peruvian carrot (Nunes et al., 2010).

Despite the imposing results, the Peruvian carrot domestic production in Brazil usesa single cultivar (Amarela de Senador Amaral- ASA) and two clones (5746, commonly called by Amarela de Carandaí, and Branca). Consequently, this fact results in high genetic uniformity which can be risky with regards of pest and disease infestations, what increases cost and impairs propagation material acquisition (Henz et al., 2005; Gomes et al., 2010). The plant has a long growing season (10 to 12 months) and its roots have very short shelf life about 7 days. As it is widely sold in natura, prices are often high, which limits its cultivation expansion, consumption and advances in research (Pires et al., 2002; Pires and Finardi-Filho, 2005).Therefore, studies on this species have increased recently aiming to acquire more productive and early genotypes and with different characteristics for processing, which would enable Peruvian carrot enhanced use as industrial raw material (Granate et al., 2004; Graciano et al., 2007; Shirai et al., 2007; Moraes et al., 2013).

By product segment, starch can be classified as dry starch, native starch, liquid starch and modified starch. The major categories to be considered while mapping the starch processing industry are food and non-food products. Use of starch in food products includes food processing and beverages. Non-food products of starch include paper, glue, thickening agent, stiffening agent and wheat paste, among others. Applications of starch include food and beverages, medicines and pharmaceuticals, ceramics, construction, textile, printing, cosmetics and colors.

There are several sources of starch such as potato, wheat, maize, sweet potato and cassava. Tuberous starch commercialization is insignificant except for cassava and 
potatoes. United States are the largest starch manufacturer with bioethanol and fructose syrups together representing $72 \%$ of starch output. China is the second largest starch supplier in the world and the second largest consumer of native starch. Output includes corn, potato, cassava and wheat starch (native and modified). The output reached 17 million tonnes in 2008 and will probably grow to 25 million tonnes by 2020 .

Brazil grows various starchy tuberous indicating an underexploited starch agricultural and industrial potential of several species, with great possibility of value aggregation mainly for Peruvian carrot. Starch is the most abundant reserve carbohydrate of plants and is mainly composed by amylose and amylopectin whose proportions strongly depend on botanical origin (Rocha et al., 2012; Schirmer et al., 2013). These molecules are associated in parallel, resulting in crystalline and micellar regions and significantly changes starch function (Biliaderis, 1991; Franco et al., 2002). Starch pasting and thermal properties may determine its specific feature and usefulness in industry. The selection of the starch for the industrial uses is made considering its availability and also its physicochemical characteristics that vary depending on the source. Due to this, each natural or native starch is considered unique (Matsuguma et al., 2009). Peruvian carrot starch displays special characteristics, which make it appropriate for industrial application in many processed foods like soups, infant foods, purees, breads and cakes as well as for other non-food uses (Rocha et al., 2008; Rocha et al., 2011). According to these reasons it can be stated that there is a need for genotypes with production characteristics satisfying short crop cycles and owning different physical and chemical properties, which would boost Peruvian carrot production chain.

Since there are few studies with different Peruvian carrot genotypes and limited information about its starch, it is necessary to elucidate this component behavior in new genotypes because several studies indicate significant differences between the genotypes of other species such as potato and cassava (Ezekiel et al., 2010; Charoenkul et al, 2011). So, the aim of this study was to evaluate new Peruvian carrot clones regarding production and starch properties as strategy to increase this species use.

\section{Results}

\section{Analyzes of roots components}

The production of roots ranged from 6.45 to $22.57 \mathrm{t} \mathrm{ha}^{-1}$. Data analysis showed differences between Peruvian carrot materials being observed smaller productions in BGH 6414 and BGH 5744 (Table 1). The dry matter content of the roots is a feature of great importance for marketing as raw materials for industrial processing. The dry matter of the roots varied from 18.03 to $23.37 \%$. The lower content was observed for BGH 7609 (Table 1). The starch content of tubers is affected by cultivar, location, climatic conditions and fertilization. The analysis of starch content in the roots showed differences between botanical materials from 14.96 to $21.41 \%$. The BGH 7609 had the lowest content of starch, which is not interesting because for cultivars intended for industrial processing of starch the obtaining of high starch content is one of the main requirements.

\section{Starches characteristics}

\section{Phosphorus and amylose contents}

Native starches generally contain small amounts of phosphorus.Results of analysis of Peruvian carrot starches showed that phosphorus contents ranged from 161 to 212.9 ppm with the highest level observed in BGH 4560 (Table 2). Apparent amylose content ranged from 20.6 to $28.2 \%$ (Table 2). All clones, except BGH 7609, have surpassed the cultivar (ASA). Among the clones, BGH 5744, BGH 6525, BGH 4560 and BGH 5741 showed the highest percentage of amylose.

\section{Pasting and thermal properties}

The pasting characteristics play an important role in the selection of a variety for use in the industry as a thickener and binder. Results of pasting properties showed differences between Peruvian carrot starches for all parameters analyzed (Table 3). The paste temperature of starches ranged from 59.80 to $61.55{ }^{\circ} \mathrm{C}$ with the highest temperature observed for BGH 7609. The peak viscosity ranged from 524.21 to 783.55 RVU. The breakdown ranged from 370.67 to $617.67 \mathrm{RVU}$, the final viscosity of starches ranged from 189.71 to 248.29 RVU and the tendency to retrogradation from 40.46 to 82.42 RVU. The data analysis showed that the starch obtained from BGH 5747 had a higher peak viscosity, lower resistance to heat and stirring, higher final viscosity and higher tendency to retrogradation when compared to other starches (Table 3). The results of the thermal properties of the starches show differences between starches obtained from different Peruvian carrot materials. Difference in transition temperatures between different starches could be attributed to difference in the degree of crystallinity (Qi et al., 2004). The initial gelatinization temperature $\left(\mathrm{T}_{\mathrm{o}}\right)$ ranged from 54.12 to $56.05{ }^{\circ} \mathrm{C}$. The peak temperature $\left(\mathrm{T}_{\mathrm{p}}\right)$ ranged from 58.19 to $59.82{ }^{\circ} \mathrm{C}$. The final temperature $\left(\mathrm{T}_{\mathrm{f}}\right)$ ranged from 62.25 to $64.18{ }^{\circ} \mathrm{C}$. Thus, range of gelatinization temperature $(\Delta \mathrm{T})$ ranged from 7.65 to $9.18{ }^{\circ} \mathrm{C}$. The enthalpy change of gelatinization $(\Delta \mathrm{H})$ of Peruvian carrot starches ranged from 13.02 to $16.50 \mathrm{~J} \mathrm{~g}^{-1}$ (Table 4). The starch BGH 5747 differed from the others due to the higher temperatures of gelatinization $\left(T_{o}, T_{p}\right.$ and $\left.T_{f}\right)$ and enthalpy of gelatinization.

The results obtained for the thermal properties of starches after retrogradation show differences between materials for all parameters. Initial temperatures were lower than those observed in gelatinization of starches. We observed higher values of $\Delta \mathrm{T}$ and lower values of $\Delta \mathrm{H}$ when compared with the results of thermal properties of gelatinization (Table 4).

\section{Pearson analysis}

Pearson correlation coefficients amongst variables of Peruvian carrot starches are shown in Table 5. Results showed that the effect of amylose appeared to dominate over the effect of phosphorus on properties of Peruvian carrot starches. When we evaluated the correlation between the variables analyzed in starches, regardless of the material used, we found that phosphorus content in starches was positively correlated to the amylose content $(\mathrm{r}=0,44, \mathrm{p} \leq 0.05)$ and negatively correlated to breakdown $(r=-0,38, p \leq 0.05)$. The amylose content of the starches was negatively correlated with the gelatinization temperatures $\left(\mathrm{T}_{0}, \mathrm{~T}_{\mathrm{p}}\right.$ and $\left.\mathrm{T}_{\mathrm{f}}\right)$ and pasting temperature, and positively correlated with enthalpy change in gelatinization $(\Delta \mathrm{H})$. 
Table 1. Total production of Peruvian carrot roots and contents of dry matter and starch.

\begin{tabular}{|c|c|c|c|}
\hline & $\begin{array}{c}\text { Total production } \\
\left(\mathrm{t} \mathrm{ha}^{-1}\right)\end{array}$ & Dry matter in roots $(\%)$ & Starch content in roots $(\%)$ \\
\hline BGH 4560 & $18.91^{\mathrm{ab}}$ & $22.68^{\mathrm{a}}$ & $18.17^{\mathrm{de}}$ \\
\hline BGH 5741 & $16.82^{\mathrm{ab}}$ & $23.37^{\mathrm{a}}$ & $21.41^{\mathrm{a}}$ \\
\hline BGH 5744 & $8.10^{c}$ & $22.30^{\mathrm{a}}$ & $18.31^{\mathrm{c}}$ \\
\hline BGH 5746 & $16.35^{\mathrm{ab}}$ & $23.04^{\mathrm{a}}$ & $20.31^{\mathrm{ab}}$ \\
\hline BGH 5747 & $21.20^{\mathrm{a}}$ & $23.04^{\mathrm{a}}$ & $17.12^{\mathrm{e}}$ \\
\hline BGH 6414 & $6.45^{\mathrm{c}}$ & $18.86^{\mathrm{b}}$ & $17.14^{\mathrm{e}}$ \\
\hline BGH 6513 & $17.06^{\mathrm{ab}}$ & $22.61^{\mathrm{a}}$ & $18.91^{\mathrm{bc}}$ \\
\hline BGH 6525 & $13.88^{\mathrm{b}}$ & $23.97^{\mathrm{a}}$ & $20.25^{\mathrm{abc}}$ \\
\hline BGH 7609 & $19.50^{\mathrm{a}}$ & $18.03^{\mathrm{b}}$ & $14.96^{\mathrm{f}}$ \\
\hline ASA & $22.57 \mathrm{a}$ & $22.06 \mathrm{a}$ & $18.86 \mathrm{e}$ \\
\hline
\end{tabular}

Means followed by the same letters in the column do not differ at $5 \%$ level by Tukey test.

Table 2. Contents of amylose and phosphorus in Peruvian carrot starches.

\begin{tabular}{lcc} 
& Amylose & $\begin{array}{c}\text { Phosphorus } \\
\text { (ppm) }\end{array}$ \\
BGH 4560 & $(\%)$ & $212.9^{\mathrm{a}}$ \\
BGH 5741 & $27.91^{\mathrm{a}}$ & $176.8^{\mathrm{b}}$ \\
BGH 5744 & $27.85^{\mathrm{ab}}$ & $170.2^{\mathrm{bcd}}$ \\
BGH 5746 & $28.21^{\mathrm{a}}$ & $161.9^{\mathrm{cd}}$ \\
BGH 5747 & $27.51^{\mathrm{b}}$ & $161.5^{\mathrm{cd}}$ \\
BGH 6414 & $23.91^{\mathrm{d}}$ & $169.4^{\mathrm{bcd}}$ \\
BGH 6513 & $26.92^{\mathrm{c}}$ & $162.4^{\mathrm{cd}}$ \\
BGH 6525 & $26.48^{\mathrm{c}}$ & $175.1^{\mathrm{bc}}$ \\
BGH 7609 & $28.00^{\mathrm{ab}}$ & $159.7^{\mathrm{d}}$ \\
ASA & $20.88^{\mathrm{e}}$ & $166.6^{\mathrm{bcd}}$ \\
\hline
\end{tabular}

Means followed by the same letters in the column do not differ at $5 \%$ level by Tukey test.

Table 3. Pasting properties of Peruvian carrot starches.

\begin{tabular}{|c|c|c|c|c|c|}
\hline & $\begin{array}{l}\text { Pasting temperature } \\
\left({ }^{\circ} \mathrm{C}\right)\end{array}$ & $\begin{array}{c}\text { Viscosity peak } \\
\text { (RVU) }\end{array}$ & Breakdown (RVU) & $\begin{array}{c}\text { Final viscosity } \\
\text { (RVU) }\end{array}$ & $\begin{array}{l}\text { Retrogradation } \\
\text { tendency (RVU) }\end{array}$ \\
\hline BGH 4560 & $60.45^{\mathrm{c}}$ & $543.67^{\mathrm{d}^{-}}$ & $381.42^{\mathrm{e}}$ & $227.96^{\mathrm{b}}$ & $65.71^{\mathrm{b}}$ \\
\hline BGH 5741 & $60.00^{\mathrm{d}}$ & $524.21^{\mathrm{e}}$ & $370.67^{\mathrm{e}}$ & $194.00^{\mathrm{e}}$ & $40.46^{\mathrm{e}}$ \\
\hline BGH 5744 & $60.40^{\mathrm{c}}$ & $569.55^{\mathrm{c}}$ & $411.34^{\mathrm{cd}}$ & $221.46^{\mathrm{b}}$ & $63.25^{\mathrm{bc}}$ \\
\hline BGH 5746 & $60.43^{\mathrm{c}}$ & $569.63^{\mathrm{c}}$ & $421.30^{c}$ & $207.46^{\mathrm{c}}$ & $59.13^{\text {cd }}$ \\
\hline BGH 5747 & $59.80^{\mathrm{d}}$ & $783.55^{\mathrm{a}}$ & $617.67^{\mathrm{a}}$ & $248.29^{\mathrm{a}}$ & $82.42^{\mathrm{a}}$ \\
\hline BGH 6414 & $60.43^{\mathrm{c}}$ & $545.79 d$ & $400.38^{\mathrm{d}}$ & $203.50^{\mathrm{cd}}$ & $58.08^{\mathrm{cd}}$ \\
\hline BGH 6513 & $59.98^{\mathrm{d}}$ & $551.88^{\mathrm{d}}$ & $408.67^{\mathrm{cd}}$ & $197.84^{\mathrm{de}}$ & $54.63^{\mathrm{de}}$ \\
\hline BGH6525 & $60.83^{\mathrm{b}}$ & $546.38^{d}$ & $401.05^{\mathrm{d}}$ & $208.63^{c}$ & $63.30^{\mathrm{b}}$ \\
\hline BGH 7609 & $61.55^{\mathrm{a}}$ & $584.92^{\mathrm{b}}$ & $442.17^{\mathrm{b}}$ & $212.17^{\mathrm{c}}$ & $69.42^{\mathrm{b}}$ \\
\hline ASA & $61.00^{\mathrm{b}}$ & $525.67^{\mathrm{e}}$ & $381.42^{\mathrm{e}}$ & $189.71^{\mathrm{e}}$ & $45.46^{\mathrm{e}}$ \\
\hline
\end{tabular}

Means followed by the same letters in the column do not differ at $5 \%$ level by Tukey test.

Pasting temperature was positively correlated with gel temperatures $\left(\mathrm{T}_{0}, \mathrm{~T}_{\mathrm{p}}, \mathrm{T}_{\mathrm{f}}\right)$ and setback was positively correlated with gelatinization enthalpy. As expected the thermal properties of starch gelatinization was negatively correlated with the properties in the retrogradation.

\section{Discussion}

In studies for the introduction of unconventional raw materials as sources of native starches a determining factor is the agricultural production, which is measured in tonnes of starch per hectare. So when we analyze the results for agricultural production, dry matter content and percentage of starch from different Peruvian carrot materials (Table 1) we can calculate the potential production of starch per hectare, which shows that the highest yield obtained under the conditions of experiment was observed to cultivar ASA. But among the clones we found low productions in BGH 6525, BGH 6414, BGH 6513 and BGH 6525. So, these clones are not the most suitable materials for indication as raw material aiming the industrial production of starch. Starch granules are made up of two glucose polymers, amylose and amylopectin. These two polymers are arranged into a complex semicrystalline granular arrangement. The amylose contents of starches obtained from Peruvian carrot were higher than the variation reported by Rocha et al. (2008) (17.81 to 21.67\%). Starches obtained from BGH 5744, BGH 6525, BGH 5741 and BGH 4560 had a higher percentage of amylose, which is interesting for several applicability (Table 2). Because of the structural stability of amylose, some high-amylose starches have played an important role in the technology of packaging films, food, medical treatment, textiles, paper making, optical fibers, printed circuit boards, and electronic chips (Hu et al., 2016). Native starches generally contain small amounts of $P$. In root and tuber starches, $\mathrm{P}$ is covalently linked to the starch in the form of $\mathrm{P}$ esters, whereas in cereal starches it occurs mostly as contaminating phospholipids (Yoneya et al., 2003; Leonel et al, 2015).The higher phosphorus content was observed in starch obtained from BGH 4560 (Table 2). 
Several results have been obtained that demonstrate that higher starch phosphorus content is closely associated with higher viscosity (Blennow et al., 2003; Lu et al, 2011) and high phosphorous content in starches contribute to increased paste viscosity and lightness (Jane et al.,1996).

Pearson analysis showed positive correlation between phosphorus content and amylose (Table 5). Phosphorus is present as phosphate monoesters and phospholipids in various starches. High phosphorus content is usually associated with a larger amount of amylopectin. However, phospholipids contents of the starch are proportional to the amylose and have a tendency to form a complex with amylose and long-branched chains of amylopectin. Phospholipids form water insoluble complexes with amylose during heating, retarding starch granule swelling.

Peroni et al. (2006) analyzing the phosphorus content in tuberous starches observed that cassava and ginger starches presented lower phosphorous content $(0.07 \%)$, whereas sweet potato and arrowroot starches displayed intermediate values( 0.014 and $0.018 \%$, respectively). Yam and canna starches showed higher phosphorous content $(0.022$ and $0.031 \%$, respectively). Thus, results of phosphorus contents in Peruvian carrot (Table 2) were similar those observed for sweet potato and arrowroot starches. The pasting properties of Peruvian carrot starches are presented in Table 3. The peak viscosity (PV), breakdown (BD), final viscosity (FV) and setback (SB) of varied greatly. The starch obtained from BGH 5747 showed higher values of $\mathrm{PV}, \mathrm{BD}, \mathrm{FV}$ and $\mathrm{SB}$, showing that this starch has low resistance to heat and stirring and high tendency to retrograde. Functional properties, such as gelatinization temperature, gel formation and paste viscosity define industrial use of starches (Bertoft et al., 2016). Evaluation of thermal properties of Peruvian carrot starch indicated that gelatinization occurs in the range of about $57^{\circ} \mathrm{C}$ (onset temperature) to $62{ }^{\circ} \mathrm{C}$ (peak temperature), involving enthalpy change around of $16 \mathrm{~J} \mathrm{~g}^{-1}$ (Rocha et al.,2008; Rocha et al., 2011). Results obtained for Peruvian carrot materials were lower than observed by these authors (Table 4) which can be due the structure of granules. According to the reports by Singh et al. (2003), the transition temperatures represent the perfection of double helical order, and the gelatinization enthalpy reflects the content of it. As shown in Table 4, compared with other starches, the BGH 7609 starch showed higher transition temperatures, low gelatinization enthalpy and narrow gelatinization temperature range. As the crystalline regions of starch granules are generally composed of amylopectin, starches with lower amylose content have higher gelling temperatures which can be observed for BGH 7609. The retrogradation is the process by which starch returns to its more ordered state, after gelatinization. During the retrogradation the amylose molecules form associations in double helix of 40 to 70 glucose units and amylopectin form double helix smaller, due to restrictions imposed by the branched structure of molecules and length of branching. This reassociation occurs in the molecular and structural form weaker than found in the native molecule. Therefore, less energy is required to melt the crystals restructured. The retrogradation behavior of Peruvian carrot starches show a decrease of melting temperatures $\left(T_{0}\right.$, $T_{p}, T_{f}$ ) with increase of range of temperatures and decrease of enthalpy change (Table 4). The percentage of retrogradation ranged from 9.56 to $32.16 \%$ with the higher value to $\mathrm{BGH}$ 7609 and lower percentage was observed to BGH 5747.

The Peruvian carrot starches are crystallographically classified as B-type polymorphic starches, or starches containing amylopectin chains with high degree of polymerization (Mweta et al., 2010; Rocha et al., 2011).
The higher retrogradation percentage of starch obtained from BGH 7609 may be related to the amylopectin structure. Amylopectin containing higher proportions of long B-type chains had an increased tendency to retrograde that resulted in a greater increase in gel storage modulus. Starch retrogradation is of great interest to food scientists and technologists since it profoundly affects the quality, acceptability and shelf-life of starch-containing foods The retrogradation is influenced by intrinsic factors as botanical sources starch composition (amylose to amylopectin ratio), granule architecture (crystalline to amorphous ratio) and other compounds (lipids) (Singh et al., 2003).

\section{Materials and Methods}

\section{Plant materials}

Nine clones from the Vegetable Germplasm Bank of the Federal University of Viçosa (UFV) (BGH 4560, 5741, 5744, 5746, 5747, 6414, 6513, 6525 and 7609) and the cultivar Amarela de Senador Amaral (ASA) were grown.

\section{Growing conditions}

Experiment was performed in Experimental Farm São Manuel of the University of São Paulo State (UNESP) at $22^{\circ} 46^{\prime} 35^{\prime \prime} \mathrm{S}$ and $48^{\circ} 34^{\prime} 44^{\prime \prime}$ W geographical coordinates and at $750 \mathrm{~m}$ altitude. It was carried out for 8 months. Maximum and minimum mean temperatures were 13 and $27{ }^{\circ} \mathrm{C}$, respectively; and rainfall was of $1022.5 \mathrm{~mm}$ during cropping period. Local soil was classified as a red yellow Oxisol with sandy texture. Soil analysis indicated the following traits: $\mathrm{pH}$ $\left(\mathrm{CaCl}_{2}\right)=5.7$; organic matter $=18 \mathrm{~g} \mathrm{dm}^{-3} ; \mathrm{P}($ resin $)=52 \mathrm{mg}$ $\mathrm{dm}^{-3} ; \mathrm{H}^{+}+\mathrm{Al}^{3+}, \mathrm{K}^{+}, \mathrm{Ca}^{2+}, \mathrm{Mg}^{2+}$ and $\mathrm{CEC}=21,2.4,25,10$ and $59 \mathrm{mmoldm}^{-3}$, respectively; $\mathrm{V}=64 \%$; and $\mathrm{B}, \mathrm{Cu}, \mathrm{Fe}, \mathrm{Mn}$ and $\mathrm{Zn}=0.29 ; 1.4 ; 46 ; 12$ and $6.6 \mathrm{mg} \mathrm{dm}^{-3}$, respectively. After soil conventional preparation it was applied $1.7 \mathrm{t} \mathrm{ha}^{-1}$ of the NPK formulated fertilizer (04-14-08) into planting furrow and $400 \mathrm{~kg} \mathrm{ha}^{-1}$ of ammonium sulfate divided into 30, 60 and 90 days after transplanting. Seedlings were prepared as Heredia Zárate et al. (2010) following disinfection for five minutes in chlorinated water; later, they were dried in shade, cut in simple bevel and pre-rooted in 72-cell tray on vegetable substrate. Thirty days after rooting, the seedlings were transplanted within 0.4 × $0.8 \mathrm{~m}$ spacing, using 20 plants per plot (two rows of 10 plants). The experimental design was randomized complete block design with four replications. During cultivation pest and disease control and sprinkler irrigation were performed following technical recommendations for the crop. Eight months after transplanting it was performed manual harvesting and starch production was quantified through root production by their starch content, in addition to root dry mass (AOAC, 2012).

\section{Starch isolation}

Washed roots were cut at $3 \mathrm{~cm}$ and then they were disintegrated for one and a half minutes with water at ratio of 1: 1 (v: v) using a 4-liter stainless steel industrial blender for the extraction of starch. The suspension was filtered through 80 and 150 mesh sieves. Residue retained on the sieves was again blended under the same conditions to remove residual starch. The starch withdrawal recovered from the fiber residue was mixed up with the first solution and kept in a cold chamber at $5^{\circ} \mathrm{C}$ for 12 hours to decanting. Supernatant was discarded, starch suspended in water until the supernatant was clear and then dried in an air circulation oven at $40{ }^{\circ} \mathrm{C}$. 
Table 4. Thermal properties of Peruvian carrot starches.

\begin{tabular}{|c|c|c|c|c|c|c|c|c|c|c|c|}
\hline Gelatinization & \multicolumn{2}{|c|}{$\mathrm{T}_{\mathrm{o}}\left({ }^{\circ} \mathrm{C}\right)$} & \multicolumn{2}{|c|}{$\mathrm{T}_{\mathrm{p}}\left({ }^{\mathrm{o}} \mathrm{C}\right)$} & \multicolumn{2}{|c|}{$\mathrm{T}_{\mathrm{f}}\left({ }^{\circ} \mathrm{C}\right)$} & \multicolumn{2}{|c|}{$\Delta \mathrm{T}\left(\mathrm{T}_{\mathrm{f}}-\mathrm{T}_{\mathrm{o}}\right)$} & \multicolumn{2}{|c|}{$\Delta \mathrm{H}\left(\mathrm{Jg}^{-1}\right)$} & \\
\hline BGH 4560 & 54.12 & $f$ & 58.40 & de & 62.43 & d & 8.31 & bc & 14.19 & de & \\
\hline BGH 5741 & 54.24 & ef & 58.19 & $\mathrm{e}$ & 62.25 & d & 8.01 & bc & 13.80 & e & \\
\hline BGH 5744 & 54.65 & $\mathrm{bc}$ & 58.36 & de & 62.38 & d & 7.74 & c & 15.53 & $\mathrm{~b}$ & \\
\hline BGH 5746 & 54.44 & de & 58.27 & $\mathrm{e}$ & 62.67 & $\mathrm{~cd}$ & 8.23 & $\mathrm{bc}$ & 16.11 & a & \\
\hline BGH 5747 & 53.40 & $\mathrm{~g}$ & 58.61 & d & 62.58 & d & 9.18 & a & 16.53 & a & \\
\hline BGH 6414 & 54.74 & $\mathrm{bc}$ & 58.63 & $\mathrm{~cd}$ & 62.39 & d & 7.65 & c & 14.94 & $\mathrm{c}$ & \\
\hline BGH 6513 & 54.38 & def & 58.22 & $\mathrm{e}$ & 62.34 & d & 7.96 & $\mathrm{bc}$ & 16.47 & a & \\
\hline BGH6525 & 54.65 & $\mathrm{~cd}$ & 58.90 & $\mathrm{bc}$ & 63.27 & $\mathrm{~b}$ & 8.62 & ab & 16.50 & a & \\
\hline BGH 7609 & 56.05 & a & 59.82 & a & 64.18 & a & 8.13 & $\mathrm{bc}$ & 14.52 & cd & \\
\hline ASA & 54.12 & $\mathrm{f}$ & 58.40 & de & 62.43 & d & 8.31 & $\mathrm{bc}$ & 14.19 & de & \\
\hline Retrogradation & & & & & & & & & & & $\mathrm{R} \%$ \\
\hline BGH 4560 & 41.61 & $a b$ & 54.70 & $\mathrm{a}$ & 61.79 & $a b c$ & 20.18 & $\mathrm{~b}$ & 2.07 & $\mathrm{f}$ & 14.59 \\
\hline BGH 5741 & 39.65 & de & 51.82 & $\mathrm{c}$ & 61.94 & $\mathrm{ab}$ & 22.29 & a & 2.09 & f & 15.15 \\
\hline BGH 5744 & 41.13 & $\mathrm{bc}$ & 53.69 & ab & 61.38 & $a b c$ & 20.25 & $\mathrm{~b}$ & 2.41 & $\mathrm{e}$ & 15.52 \\
\hline BGH 5746 & 39.78 & de & 53.83 & ab & 61.34 & $a b c$ & 21.56 & $\mathrm{ab}$ & 2.85 & $\mathrm{c}$ & 17.69 \\
\hline BGH 5747 & 42.50 & a & 53.41 & ab & 60.98 & $\mathrm{bc}$ & 18.47 & $\mathrm{~cd}$ & 1.58 & $\mathrm{~h}$ & 9.56 \\
\hline BGH 6414 & 39.36 & $\mathrm{e}$ & 54.26 & a & 62.10 & a & 22.75 & a & 2.68 & d & 17.94 \\
\hline BGH 6513 & 41.32 & $\mathrm{bc}$ & 53.83 & ab & 61.28 & $a b c$ & 19.97 & bc & 2.41 & $\mathrm{e}$ & 14.63 \\
\hline BGH6525 & 40.50 & $\mathrm{~cd}$ & 52.91 & bc & 61.96 & $\mathrm{ab}$ & 21.46 & ab & 3.23 & b & 19.58 \\
\hline BGH 7609 & 39.04 & $\mathrm{e}$ & 50.31 & d & 62.14 & $\mathrm{a}$ & 23.10 & $\mathrm{a}$ & 4.67 & a & 32.16 \\
\hline ASA & 41.61 & $a b$ & 54.70 & $\mathrm{a}$ & 61.79 & $a b c$ & 20.18 & $\mathrm{~b}$ & 2.07 & f & 13.67 \\
\hline
\end{tabular}

$\mathrm{T}_{0}=$ initial temperature; $\mathrm{T}_{\mathrm{p}}=$ peak temperature; $\mathrm{T}_{\mathrm{f}}=$ final temperature; $\Delta \mathrm{T}_{\mathrm{l}}=$ range of temperature; $\Delta \mathrm{H}=$ enthalpy change, $\mathrm{R}(\%)$, percentage of retrogradation. Means followed by the same letters in the column do not differ at $5 \%$ level by Tukey test.

Table 5.Pearson correlation coefficients of starch properties.

\begin{tabular}{|c|c|c|c|c|c|c|c|c|c|c|c|c|c|c|c|c|c|}
\hline Variables & 1 & 2 & 3 & 4 & 5 & 6 & 7 & 8 & 9 & 10 & 11 & 12 & 13 & 14 & 15 & 16 & 17 \\
\hline 1 Phosphorus & 1 & $0.44 *$ & & & & & & & & & & & & & $-0.38^{*}$ & & \\
\hline 2 Amylose & & 1 & $-0.46^{* *}$ & $-0.69 * * *$ & $-0.52 * * *$ & & $0.42 *$ & & & & & & $-0.53 * *$ & & & & \\
\hline $3 \mathrm{~T}_{\text {ogel }}$ & & & 1 & $0.78 * * *$ & $0.74 * * *$ & $-0.46 * *$ & & $-0.52 * *$ & $-0.52 *$ & $0.37 *$ & $0.51 * *$ & $0.81 * * *$ & $0.86 * * *$ & $-0.47 * *$ & $-0.42 *$ & $-0.40 *$ & \\
\hline $4 \mathrm{~T}_{\text {pgel }}$ & & & & 1 & $0.89^{* * *}$ & & & & $-0.51 * *$ & & & $0.64 * * *$ & 0.82 *** & & & & \\
\hline $5 \mathrm{~T}_{\mathrm{fgel}}$ & & & & & 1 & & & & $-0.59 * * *$ & & & $0.76 * * *$ & $0.82 * * *$ & & & & \\
\hline $6 \Delta \mathrm{T}_{\mathrm{gel}}$ & & & & & & 1 & $0.42 *$ & $0.40 *$ & & & $-0.39 *$ & & & $0.68 * * *$ & $0.62 * * *$ & $0.69 * * *$ & $0.61 * * *$ \\
\hline $7 \Delta \mathrm{H}_{\text {gel }}$ & & & & & & & 1 & & & & & & $-0.37^{*}$ & $0.45^{*}$ & $0.46^{* * *}$ & $0.48^{* *}$ & $0.55^{* *}$ \\
\hline $8 \mathrm{~T}_{\text {Oret }}$ & & & & & & & & 1 & $0.51 * *$ & $-0.69 * * *$ & $-0.97 * * *$ & $-0.70 * * *$ & & $0.37 *$ & & & \\
\hline $9 \mathrm{~T}_{\text {pret }}$ & & & & & & & & & 1 & $-0.43 *$ & $-0.52^{* *}$ & $-0.66 * * *$ & $-0.38^{*}$ & & & & \\
\hline $10 \mathrm{~T}_{\text {fret }}$ & & & & & & & & & & 1 & $0.84 * * *$ & $0.57 * *$ & & & & & \\
\hline $11 \Delta \mathrm{T}_{\mathrm{ret}}$ & & & & & & & & & & & 1 & $0.71 * * *$ & & $-0.38 *$ & $-0.37 *$ & & \\
\hline $12 \Delta \mathrm{H}_{\mathrm{ret}}$ & & & & & & & & & & & & 1 & $0.68 * * *$ & & & & \\
\hline $13 \mathrm{TP}$ & & & & & & & & & & & & & 1 & & & & \\
\hline $14 \mathrm{PV}$ & & & & & & & & & & & & & & 1 & $0.99 * * *$ & $0.79 * * *$ & $0.78^{* * *}$ \\
\hline $15 \mathrm{BK}$ & & & & & & & & & & & & & & & 1 & $0.76^{* * * *}$ & $0.79 * * *$ \\
\hline $16 \mathrm{FV}$ & & & & & & & & & & & & & & & & 1 & $0.94 * * *$ \\
\hline $17 \mathrm{SB}$ & & & & & & & & & & & & & & & & & 1 \\
\hline
\end{tabular}

$\mathbf{T}_{\text {ogel }}=$ initial temperature of gelatinization; $\mathbf{T}_{\text {pgel }}=$ peak temperature of gelatinization $; \mathbf{T}_{\text {ggel }}=$ final temperature of gelatinization $; \Delta \mathbf{T}_{\text {gel }}=$ range of temperature; $\Delta \mathbf{H}_{\text {gel }}=$ enthalpy change of gelatinization; $\mathbf{T}_{\text {oret }}=$ initial temperature of retrogradation; ing $\mathrm{BK}=\mathrm{beakdown} ; \mathrm{FV}=$ final viscosity; $\mathrm{SB}=$ setback: $* \mathrm{p}<0.05$ 


\section{Analysis of starches}

The amylose content of starch was determined using the method described by ISO 6647 (1987). The content of P in potato starches was analyzed according to the methodology described by Malavolta et al. (1997). Analyses were carried out in triplicate.

The thermal properties of potato starches were analyzed using a differential scanning calorimeter (DSC) Pyris 1 (Perkin Elmer, USA). Starch samples (2.0 mg, dry basis) were weighed into aluminum pans, mixed with deionized water $(6 \mu \mathrm{L})$ and sealed. The sealed pans were kept at room temperature for $2 \mathrm{~h}$ for balance and heated at a rate of $10^{\circ} \mathrm{C}$ $\min ^{-1}$ from $25{ }^{\circ} \mathrm{C}$ to $100{ }^{\circ} \mathrm{C}$. An empty pan was used as reference. After running the samples in DSC, they were refrigerated at $5^{\circ} \mathrm{C}$ for 14 days and analyzed again under the same conditions to determine the thermal properties of retrograded starches. The gelatinization temperature (initial, peak and final) and the enthalpy change of native and retrograded starches were determined using the Pyris 1 software from Perkin Elmer, USA. This analysis was carried out in triplicate.

For the analysis of the pasting properties was used the Rapid Visco Analyzer (RVA 4, Newport Scientific, Australia). The starch suspensions ( $2.5 \mathrm{~g}$ of starch in $25 \mathrm{ml}$ of water), corrected for the basis of $14 \%$ of moisture, passed by the programming: $50{ }^{\circ} \mathrm{C}$ for $1 \mathrm{~min}$, heating from $50^{\circ} \mathrm{C}$ to 95 ${ }^{\circ} \mathrm{C}$ at a rate of $6{ }^{\circ} \mathrm{C} \mathrm{min}{ }^{-1}$, maintaining the paste at $95^{\circ} \mathrm{C}$ for 5 minutes, cooling from $95{ }^{\circ} \mathrm{C}$ to $50{ }^{\circ} \mathrm{C}$ at a rate of $6{ }^{\circ} \mathrm{C} \mathrm{min}{ }^{-1}$. The viscosity was expressed as rapid visco unit (RVU) (1 RVU $=12 \mathrm{cP}$ ). From the graph obtained were evaluated: pasting temperature, maximum viscosity (peak), breakdown, final viscosity and setback. This analysis was carried out in triplicate.

\section{Statistical analysis}

Data were subjected to analysis of variance using the SAS statistical software. When appropriate, the difference amongst means was determined using Tukey's multiple comparisons at the 0.05 probability level. Pearson correlation coefficients were determined to evaluate relationships between starch variables.

\section{Conclusions}

In view of the obtained results were observed that Peruvian carrot genotypes showed varied production of root, dry mass and starch content suitable for commercial crops and starch extraction. Their starches have content of amylose and phosphorus, pasting and thermal properties that are attractive for food industries.

\section{Acknowledgements}

The authors thank the National Council for Scientific and Technological Development (CNPq- Brazil) for financial support and Federal University of Viçosa for granting Peruvian carrot genotypes by the Researcher Maria José Granate.

\section{References}

AOAC (Association of Official Analytical Chemists International) (2012) Official methods of analysis of Association of Official Analytical Chemists International, 19ed. Gaithersburg.
Bertoft E, Annor GA, Shenc X, Rumpagaporn P, Seetharaman K, Hamaker BR (2016) Small differences in amylopectin fine structure may explain large functional differences of starch. Carb Polym. 140:113-121.

Biliaderis CG (1991) The structure and interactions of starch with food. Can J Physiol Pharm. 69:60-78.

Blennow A, Bay-Smidt AM, Leonhardt P, Bandsholm O, Madsen MH (2003) Starch paste stickiness is a relevant native starch selection criterion for wet-end paper manufacturing. Starch. 55:381-389.

Charoenkul N, Uttapap D, Pathipanawat W, Takeda Y (2011) Physicochemical characteristics of starches and flours from cassava varieties having different cooked root textures. LWT-Food Sci Technol. 44:1774-1781.

Ezekiel R, Rana G, Singh N, Singh S (2010) Physicochemical and pasting properties of starch from stored potato tubers. J Food Sci Technol. 47:195-201.

Franco CML, Cabral RAF, Tavares DQ (2002) Structural and physicochemical characteristics of lintnerized native and sour cassava starches. Starch. 54:469-475.

Gomes HE, Heredia Zárate NA, Vieira MC, Gassi RP, Torales EP, Macedo RV (2010) Yield of cuttings and commercial roots of 'Amarela de Carandaí' Peruvian carrot as a function of spacing and hilling. Semina. 31:1121-1132.

Graciano JD, Heredia Zárate NA, Vieira MC, Rosa YBCJ, Sediyama MAN (2007) Spaces between rows and plants on yield of Branca Peruvian carrot. Ciênc Agrotec. 31:16881695.

Granate MJ, Sediyama MAN, Oliveira LR, Cruz CD, Puiatti M (2004) Clonal selection in arracacha breeding. Crop Breed Appl Biot. 4:105-110.

HenzGP, Reifschneider FJB, Santos FF (2005) Reaction of arracacha genotypes to the root soft rot caused by Pectobacterium chrysanthemi. Pesq Agropec Bras. 40:9598.

Heredia Zárate NAH, Schwan-Estrada KRF, Vieira MC, Helmich M, Macedo RV, Heid DM (2010) Sprouting and yield of 'Amarela de Carandaí' Peruvian carrot from cuttings disinfected with eucalyptus oil and rooted in trays. Bragantia. 69:871-875.

Heredia Zárate NA, Vieira MC, Rech J, Quast A, Pontim BCA, Gassi RP (2008) Yield and gross income of arracacha in monocrop and intercropping with the Japanese bunching onion and parsley. Hortic Bras. 26:277-281.

Hu L, Zhenga Y, Peng Y, Yao C, Zhang H (2016) The optimization of isoamylase processing conditions for the preparation of high-amylose ginkgo starch. Int $\mathrm{J}$ Biol Macromol. 86:105-111.

International Organization for Standardization (1987) ISO 6647: normeinternacionale: riz determination de la teneuren amylose. $4 \mathrm{p}$. Geneva.

Jane J, Kasemsuwan T, Chen JF, Juliano B (1996) Phosphorous in rice and others starches. Cereal Foods World. 41:827-832.

Leonel M, Feltran JC, Aguiar EB, Fernandes AM, Peressin VA, Bicudo SJ (2015) Mandioca (Manihot esculenta Crantz). In: Leonel M, Fernandes AM, Franco CML (Coord.) Culturas amiláceas: batata-doce, inhame, mandioca e mandioquinha-salsa. CERAT/UNESP, Botucatu.

Lu Z-L, Yada RY, Liu Q, Bizimungu B, Murphy A, De Koeyer D et al.(2011) Correlation of physicochemical and nutritional properties of dry matter and starch in potatoes grown in different locations. Food Chem. 126:1246-1253.

MalavoltaE, Vitti GC, Oliveira AS (1997)Avaliação do estado nutricional de plantas: Princípios e aplicações. Potafos. 319p. Piracicaba, São Paulo. 
Matsuguma LS, Lacerda LG, SchnitzlerE, Carvalho Filho MAS, Franco CML, Demiate IM (2009) Characterization of native and oxidized starches of two varieties of Peruvian carrot (Arracacia xanthorrhiza B.) from two production areas of Paraná State, Brazil. Braz Arch Biol Techn. 52:701-713.

Moraes J, Alves FS, Franco CML (2013) Effect of ball milling on structural and physicochemical characteristics of cassava and Peruvian carrot starches. Starch. 65:200-209.

Mweta DE, Labuschagne MT, Bonnet S, Swarts J, Saka JDK (2010) Isolation and physicochemical characterization of starch from cocoyam (Colocasia esculenta) grown in Malawi. J Sci Food Agr. 90:1886-1896.

Nunes EE, Vilas Boas EV, Piccoli RH, Xisto ALRP, Vilas Boas BM (2010) Effect of different temperatures on the quality of fresh-cut Peruvian carrot. Hortic Bras. 28:311315.

Pedreschi R, Betalleluz-Pallardel I, Chirinos R, Curotto C, Campos D (2011) Impact of cooking and drying on the phenolic, carotenoid contents and in vitro antioxidant capacity of Andean arracacha (Arracacia xanthorrhiza Bancr.) root. Food Sci Technol Int.17:319-330.

Peroni FGH, Rocha TS, Franco CML (2006) Some structural and physicochemical characteristics of tuber and root starches. Food Sci Tech Int. 12:505-513.

PiresTCR, Finardi-Filho F (2005) Extraction and assay of pectie enzymes from Peruvian carrot (Arracacia xanthorrhiza Bancroft.). Food Chem.89:85-92.

Pires TCR, Veiga EM, Finardi-Filho F (2002) Amylolytic enzymes from Peruvian carrot (Arracacia xanthorrhiza Bancroft). CiêncTecnolAliment.22:278-284.

Qi X, Tester RF, Snape CE, Yuryev V, Wasserman LA, Ansell R (2004). Molecular basis for the gelatinisation and swelling characteristics of waxy barley starches grown at the same location during the same season. Part II. Crystallinity and gelatinisation characteristics. J Cereal Sci. 39:57-66

Rocha TS, Felizardo SG, Jane J, Franco CML (2012) Effect of annealing on the semicrystalline structure of normal and waxy corn starches. Food Hydrocoll. 29:93-99.

Rocha TS, Demiate IM, Franco CML (2008) Structural and physicochemical characteristics of Peruvian carrot (Arracacia xanthorrhiza) starch. Ciênc Tecnol Aliment.28:620-628.
Rocha TS, Cunha VA, Jane JL, Franco CML (2011) Structural characterization of Peruvian carrot (Arracacia xanthorrhiza) starch and the effect of annealing on its semicrystalline structure. J Agr Food Chem.59:4208-4216.

Schirmer M, Höchstötter A, Jekle M, Arendt E, Becker T (2013) Physicochemical and morphological characterization of different starches with variable amylose/amylopectin ratio. Food Hydrocoll. 32:52-63.

Shirai MA, Haas A, Ferreira GF, Matsuguma LS, Franco CML, Demiate IM (2007) Physicochemical characterization and applications in foods of starches modified by oxidative treatment. Ciênc Tecnol Aliment. 27:239-247.

Singh N, Singh J, Kaur L, Sodhi NS, Gill BS (2003) Morphological, thermal and rheological properties of starches from different botanical sources. Food Chem. 81:219-231.

Takeiti C, Fakhouri F, Ormenese R, Steel CJ, Collares $\mathrm{F}(2007)$ Freeze-thaw stability of gels prepared from starches of non-conventional sources. Starch.59:156-160.

Vietmeyer ND (1986) Lesser-known plants of potential use in agriculture and forestry. Science. 232:1379-1384.

Yoneya T, Ishibashi K, Hironaka K, Yamamoto K (2003) Influence of cross-linked potato starch treated with $\mathrm{POCl} 3$ on DSC, rheological properties and granule size. Carbohyd Polym. 53:447-457. 